\title{
Agronomic traits and yield of organic maize under no-tillage system ${ }^{1}$
}

\author{
Lamara Freitas Brito ${ }^{2}$, João Carlos Cardoso Galvão², \\ Jeferson Giehl' ${ }^{2}$, Silvane de Almeida Campos ${ }^{2}$, Steliane Pereira Coelho ${ }^{2}$
}

\section{ABSTRACT}

The no-tillage farming has become a popular practice in Brazil, but problems with weed control and plant nutrition persist under organic production systems. This study aimed at evaluating the agronomic traits and yield of maize, after using different off-season cover crops under two organic no-tillage systems. A randomized block design, with a $7 \times 2$ factorial scheme, being 7 treatments (weeds; black oat monoculture; sunflower; white lupin intercropped with black oat in rows; white lupin intercropped with black oat by broadcasting; white lupin monoculture; and no cover crop) and 2 cropping systems (maize alone and intercropped with jack bean), and four replications was used. The agronomic traits evaluated were plant height, first-ear insertion height, stem diameter, prolificacy, 1,000 grain weight, grain yield and nitrogen released at 60 days of mulch decomposition. White lupin straw in monoculture and intercropped with black oat release a higher amount of $\mathrm{N}$ during the decomposition process and, consequently, these treatments increase maize yield. Intercropping with jack bean within the same row as maize reduces its yield potential under an organic no-tillage system.

KEYWORDS: Zea mays; Canavalia ensiformis; cover crops; organic fertilization.

\section{INTRODUCTION}

Maize, a versatile cereal, in terms of consumption, is considered one of Brazil's most important agricultural products. Organic maize is used in the meat supply chain, since it is a component of the feed given to organically farmed poultry and pigs (Môro \& Frische-Neto 2015).

Organic vegetable farming generally involves significant soil displacement in the form of plowing and harrowing. These practices are not in line with

\section{RESUMO}

Características agronômicas e

produtividade de milho orgânico sob plantio direto

A prática de plantio direto se popularizou no Brasil, porém, em sistemas orgânicos de produção, persistem entraves quanto ao manejo de plantas daninhas e nutrição de plantas. Objetivou-se avaliar as características agronômicas e a produtividade de milho, após a utilização de diferentes plantas de cobertura na entressafra, em dois sistemas de plantio direto orgânico. Utilizou-se delineamento em blocos casualizados, com 4 repetições, em esquema fatorial 7 x 2 , sendo 7 manejos (plantas espontâneas; aveia preta em monocultivo; girassol; consórcio em fileiras de tremoço branco e aveia preta; consórcio à lanço de tremoço branco e aveia preta; tremoço branco em monocultivo; e manejo sem cobertura vegetal) e 2 modos de cultivo (milho solteiro e consorciado com feijão-de-porco). Avaliaram-se as seguintes características agronômicas: altura da planta, altura da inserção da espiga principal, diâmetro do colmo, prolificidade, massa de 1.000 grãos, produtividade de grãos e nitrogênio liberado aos 60 dias de decomposição da palhada. A palhada de tremoço branco em monocultivo e os consórcios com aveia preta liberam maior quantidade de $\mathrm{N}$ durante o processo de decomposição e, consequentemente, estes manejos elevam a produtividade do milho. O consórcio de feijão-de-porco na mesma linha de cultivo do milho reduz seu potencial produtivo em sistema de plantio direto orgânico.

PALAVRAS-CHAVE: Zea mays; Canavalia ensiformis; plantas de cobertura; adubação orgânica.

the principles of organic farming, which prioritizes the maintenance of cover crops and increase of soil organic matter. Thus, one alternative is to adapt the no-tillage farming to organic systems, in order to comply with the concept of sustainability (Mello \& Brum 2013).

No-tillage farming provides a range of benefits, such as increasing the amount of soil organic matter, reducing erosion, improving the soil chemical, physical and biological attributes, enhancing fertility and showing good results in the recovery of soil 
qualitative characteristics, as well as increasing its production capacity (Berté et al. 2010).

Cover crops are widely used in no-tillage farming to form mulch with an intermediate carbon to nitrogen $(\mathrm{C}: \mathrm{N})$ ratio, and the association of different species may be an alternative to better synchronize the release of nutrients and their absorption by crops (Silva et al. 2007). Generally, legumes are intercropped with grasses, producing crop residues with the slow decomposition of grasses and a rapid decomposition rate of legumes, adding nitrogen $(\mathrm{N})$ to the soil. Nitrogen is the most demanded nutrient by maize, since its deficiency limits crop yield (Farinelli \& Lemos 2012). As such, the study of different cover crops in the organic no-tillage farming of maize is highly significant.

No-tillage farming remains a challenge in organic farming, when the goal is to achieve high yields (Darolt \& Skora Neto 2002). However, it is important to develop new technological researches adapted to organic farming, in which management is restricted according to legislation (Coelho 2014). Studies on management practices associated with soil conservation in organic no-tillage farming of maize have shown improvements in fertility and crop yield. Cancellier et al. (2011) used different organic fertilizers along rows of growing maize and observed a similar yield to that obtained with conventional chemical fertilization. Long-term fertilization with the application of organic compost conserves the soil fertility and maintains the yield of maize crops (Cruz et al. 2006).

Another way of diversifying the management of organic systems is by intercropping two or more species, either with commercial value or used as green fertilizer. In addition to favoring weed control, intercropping enables nutrient cycling and contributes to fertilization for the subsequent planting of crops (Gontijo Neto et al. 2014). Studies on organic maize farming under no-tillage systems, using intercropping with jack beans, have shown that up to 6 jack bean plants $\mathrm{m}^{-1}$, along the maize row, did not affect grain yield, allowing the control of weeds that might compete with the cash crop (Fontanétti 2008). In organic farming, legumes are used for intercropping and the formation of mulch suited to the no-tillage system.

The present study aimed at evaluating the agronomic traits and yield of maize, using different cover crops and two organic no-tillage systems.

\section{MATERIAL AND METHODS}

The experiment was carried out at the experimental station of the Universidade Federal de Viçosa, in Coimbra, Minas Gerais State, Brazil. The soil at the experimental area is a Red-Yellow Argisol (Ultisol) (Embrapa 2013). The climate is classified as mesothermal, with an average annual temperature of $19.4^{\circ} \mathrm{C}$ and average annual rainfall of $1,165 \mathrm{~mm}$ (Ramos et al. 2009). Additional irrigation was performed to ensure the establishment of cover crops and in the initial stages of maize growth.

Soil samples were collected at a depth of $0-10 \mathrm{~cm}$, before the experiment. The results were as it follows: $\mathrm{pH}$ in water $=5.70 ; \mathrm{P}=$ $9.4 \mathrm{mg} \mathrm{dm}^{-3} ; \mathrm{K}=350 \mathrm{mg} \mathrm{dm}^{-3} ; \mathrm{Ca}=25 \mathrm{mmol}_{\mathrm{c}} \mathrm{dm}^{-3}$; $\mathrm{Mg}=13 \mathrm{mmol}_{\mathrm{c}} \mathrm{dm}^{-3} ; \mathrm{Al}^{3+}=0 \mathrm{mmol}_{\mathrm{c}} \mathrm{dm}^{-3} ; \mathrm{H}+\mathrm{Al}=$ $46.2 \mathrm{mmol}_{\mathrm{c}} \mathrm{dm}^{-3}$; sum of bases $=47 \mathrm{mmol}_{\mathrm{c}} \mathrm{dm}^{-3}$; effective cation exchange capacity $=47 \mathrm{mmol}_{\mathrm{c}} \mathrm{dm}^{-3}$; potential cation exchange capacity $=93.2 \mathrm{mmol}_{\mathrm{c}} \mathrm{dm}^{-3}$; base saturation $=50 \%$; organic matter $=39.9 \mathrm{~g} \mathrm{~kg}^{-1}$; and remaining $\mathrm{P}=23.2 \mathrm{mg} \mathrm{L}^{-1}$. Determinations were performed according to Silva (2009).

The previous crop was maize grown under an organic no-tillage system. The experiment was conducted in the 2015/2016 growing season, using maize in an organic no-tillage system and a randomized block design, in a $7 \times 2$ factorial scheme, being seven treatments (weed-based mulch; no cover crop - periodic weeding; black oat mulch; sunflower mulch; white lupin intercropped with black oat mulch - in rows; white lupin intercropped with black oat mulch - by broadcasting; and white lupin mulch), namely six cover crops and one treatment with no cover crop, and two cropping systems [maize alone and intercropped with jack bean (Canavalia ensiformis)], with four replications.

The cover crops were planted in June 2015 and mowed at the full flowering stage for the subsequent planting of the maize crop. The black oat (Avena strigosa) Embrapa 29 cultivar was planted by broadcasting at a density of $80 \mathrm{~kg} \mathrm{ha}^{-1}$ of seeds. The sunflower (Helianthus annuus) Catissol 01 variety was planted in furrows spaced $0.90 \mathrm{~m}$ apart, reaching a population of 55,000 plants ha ${ }^{-1}$ after thinning. The weeds that emerged, taken from the local seed bank, were kept as plant cover in the respective treatment. The white lupin (Lupinus albus) monoculture was hand planted (broadcasting) at a density of $85 \mathrm{~kg} \mathrm{ha}^{-1}$ of seeds. The black oat intercropped with white 
lupin was planted in rows spaced $0.33 \mathrm{~m}$ apart, with a density of $30 \mathrm{~kg} \mathrm{ha}^{-1}$ of seeds for the former and $40 \mathrm{~kg} \mathrm{ha}^{-1}$ of seeds for the latter. The intercropping of the same two species planted by broadcasting used $30 \%$ more seeds.

The experimental unit $\left(19.2 \mathrm{~m}^{2}\right)$ consisted of six 4-meter-long rows of maize spaced $0.80 \mathrm{~m}$ apart. The open pollinated maize AL Bandeirante variety (tall and with a normal growth cycle) was used. Maize was planted at a density of 6 seeds $\mathrm{m}^{-1}$, reaching a population of 50,000 plants ha ${ }^{-1}$, after thinning at 35 days after emergence. Jack bean seeds were planted simultaneously to maize and within the same rows, at a density of 5 plants $\mathrm{m}^{-1}$, with the aid of manual seed planters.

In the fourth phenological stage (V4), with four fully expanded maize leaves, $40 \mathrm{~m}^{3} \mathrm{ha}^{-1}$ of organic compost were applied alongside the row, without incorporation (Fancelli 2015). The results of the chemical analysis of the compost (dry matter), conducted according to Silva (2009), were as it follows: organic carbon $=106.1 \mathrm{~g} \mathrm{~kg}^{-1}$; total $\mathrm{N}=11 \mathrm{~g} \mathrm{~kg}^{-1} ; \mathrm{P}=3.8 \mathrm{~g} \mathrm{~kg}^{-1} ; \mathrm{K}=12 \mathrm{~g} \mathrm{~kg}^{-1} ; \mathrm{Ca}=$ $9.4 \mathrm{~g} \mathrm{~kg}^{-1} ; \mathrm{Mg}=4.2 \mathrm{~g} \mathrm{~kg}^{-1} ; \mathrm{S}=5.3 \mathrm{~g} \mathrm{~kg}^{-1} ; \mathrm{Zn}=$ $158 \mathrm{mg} \mathrm{kg}^{-1} ; \mathrm{Fe}=37.686 \mathrm{mg} \mathrm{kg}^{-1} ; \mathrm{Mn}=239 \mathrm{mg} \mathrm{kg}^{-1}$; $\mathrm{Cu}=68 \mathrm{mg} \mathrm{kg}^{-1} ; \mathrm{B}=13.1 \mathrm{mg} \mathrm{kg}^{-1} ; \mathrm{Na}=1.8 \mathrm{~g} \mathrm{~kg}^{-1}$; and $\mathrm{pH}=8.83$.

When the maize reached the stages V3 and V6, weeding was performed twice, with a backpack brushcutter. Maize grown without cover crop was weeded manually.

To determine the biomass production of cover crops, a $0.25 \mathrm{~m} \times 0.25 \mathrm{~m}$ quadrant was randomly placed in the plot, with the exception of sunflower plants, which were whole collected along one linear meter. The plants were cut at ground level, weighed and dried in an oven at $70{ }^{\circ} \mathrm{C}$, for $72 \mathrm{~h}$.

The experimental units used to evaluate the $\mathrm{N}$ cycling consisted of $2 \mathrm{~mm}$ mesh litterbags measuring $0.25 \mathrm{~m}$ x $0.25 \mathrm{~m}$ (Rezende et al. 1999, Amado et al. 2002). A total of $60 \mathrm{~g}$ of green matter (fragments of material from each mulch treatment) were placed in each litterbag, which were then taken to the field and placed in the respective plots from which the mulch originated. The assessment was conducted after mowing and at 60 days after the decomposition of the plant residue. The litterbags were collected and placed in a forced air oven at $65^{\circ} \mathrm{C}$, until constant mass, to determine the residual dry matter and $\mathrm{N}$ content. The residue was ground in a Wiley Star
FT80 mill and submitted to chemical analysis in the laboratory to determine the total $\mathrm{N}\left(\mathrm{dag} \mathrm{kg}^{-1}\right)$, in accordance with Silva (2009).

The residual dry matter was estimated based on the ratio between the decomposition of dry matter from the litterbags and initial dry matter, being multiplied by the nutrient content in the mulch to determine the amount of residual nutrients in the mulch $\left(\mathrm{kg} \mathrm{ha}^{-1}\right)$. The amount of $\mathrm{N}$ released was calculated based on the difference between the residual nutrient concentration in the mulch at 60 days, in relation to initial levels.

The following agronomic traits were evaluated during the R6 stage of the maize: average plant height, in meters (measured from the ground to the insertion point of the highest leaf of four plants from the experimental plot); first-ear insertion height, in meters (measured from the ground to the insertion point of the first ear on four plants); stem diameter of four plants, in mm (measured using a digital pachymeter); prolificacy (number of ears per plant); 1,000 grain weight, in grams (calculated based on three repetitions of 100 grains per experimental plot); and grain yield, in $\mathrm{kg} \mathrm{ha}^{-1}$. All the ears in the harvest area of the plot were manually collected and grain yield was corrected for $13 \%$ humidity.

The data were submitted to analysis of variance and the means compared by the Tukey test at $5 \%$, using the Assistat statistical software, version 7.7 (Silva \& Azevedo 2016).

\section{RESULTS AND DISCUSSION}

There was a difference in biomass accumulation among the cover crops (Table 1). Only the dry matter production of weeds failed to reach the minimum amount of biomass $\left(6 \mathrm{tha}^{-1}\right)$ required for no-tillage farming to cover the soil (Alvarenga et al. 2001). Black oat obtained similar dry matter results to the treatment with weeds, but did not differ from those using sunflower and white lupin (in monoculture or intercropped), which produced the highest amounts of biomass.

Nitrogen cycling and release by the mulch were dependent on the species used and not influenced by the cropping method. The amount of $\mathrm{N}$ released in the different mulches up to 60 days of decomposition indicates that the treatment with white lupin mulch in monoculture did not differ from the white lupin intercropped with black oat (in rows 
and by broadcasting) and sunflower. Treatments with weed-based mulch and black oat had the lowest $\mathrm{N}$ release and did not differ from sunflower (Figure 1).

Since it is a species from the Fabaceae family, white lupin has a low $\mathrm{C}: \mathrm{N}$ ratio, resulting in a greater nitrogen contribution during its rapid decomposition and better cycling of the nutrient, releasing around $200 \mathrm{~kg} \mathrm{ha}^{-1}$ of $\mathrm{N}$ after 60 days of mulch decomposition. According to Amado et al. (2000), using legumes as a nitrogen source is a good alternative to supplement fertilization with $\mathrm{N}$, increasing the cash crop yield. Wutke et al. (2014) reported that white lupin can fix at 128-268 kg ha-1 year-1 of $\mathrm{N}$, reducing the need for nitrogen fertilizers (Lázaro et al. 2013) and thereby contributing to the sustainability of the agroecosystem.

White lupin intercropped with black oat (in rows and by broadcasting) also prompted a significant $\mathrm{N}$ release during mulch decomposition. According

Table 1. Average values for dry matter production in cover crops (DMC).

\begin{tabular}{lc}
\hline \multicolumn{1}{c}{ Cover crop } & DMC $\left(\mathrm{kg} \mathrm{ha}^{-1}\right)$ \\
\hline Weeds & $4.940 \mathrm{~b}^{*}$ \\
Black oat & $7.020 \mathrm{ab}$ \\
Sunflower & $9.012 \mathrm{a}$ \\
White lupin + black oat (rows) & $9.360 \mathrm{a}$ \\
White lupin + black oat (broadcasting) & $9.320 \mathrm{a}$ \\
White lupin & $9.800 \mathrm{a}$ \\
\hline * Means followed by the same letter do not differ statistically according to the \\
Tukey test at $5 \%$.
\end{tabular}

to Heinrichs et al. (2001), intercropping grasses and legumes may result in a biomass with an intermediate $\mathrm{C}: \mathrm{N}$ ratio and produce crop residues that can act to protect the soil against erosion and provide nitrogen for maize. The intercropping of these two species causes less competition for the $\mathrm{N}$ present in the soil, since legumes use nitrogen from the atmosphere (Favarato 2015).

The sunflower treatment achieved intermediate $\mathrm{N}$ release during the decomposition of its residues over a period of up to 60 days. According to Fageria et al (2005), some non-leguminous cover crops have a high $\mathrm{N}$ scavenging capacity. The authors reported the dry matter yield and $\mathrm{N}$ uptake values as indicators of $\mathrm{N}$ uptake capacity. The sunflower can be considered one of such species, since it produced more than $9,000 \mathrm{~kg} \mathrm{ha}^{-1}$ of biomass and recycled around $100 \mathrm{~kg} \mathrm{ha}^{-1}$ of $\mathrm{N}$, thereby benefitting the subsequent crop.

The seed bank that produced the weed-based mulch consisted primarily of grasses. This treatment and the black oat mulch released the lowest amount of N. For grasses, this behavior is attributed to the high $\mathrm{C}: \mathrm{N}$ ratio of the crop residues, which may have immobilized nitrogen in the soil through the action of microorganisms (Silva et al. 2007). Thus, these authors argue that intercropping grasses and legumes aims at increasing the $\mathrm{N}$ availability in the system.

Treatments with different cover crops did not influence plant height, first-ear insertion height, stem diameter or prolificacy, with mean values of $2.25 \mathrm{~m}$,

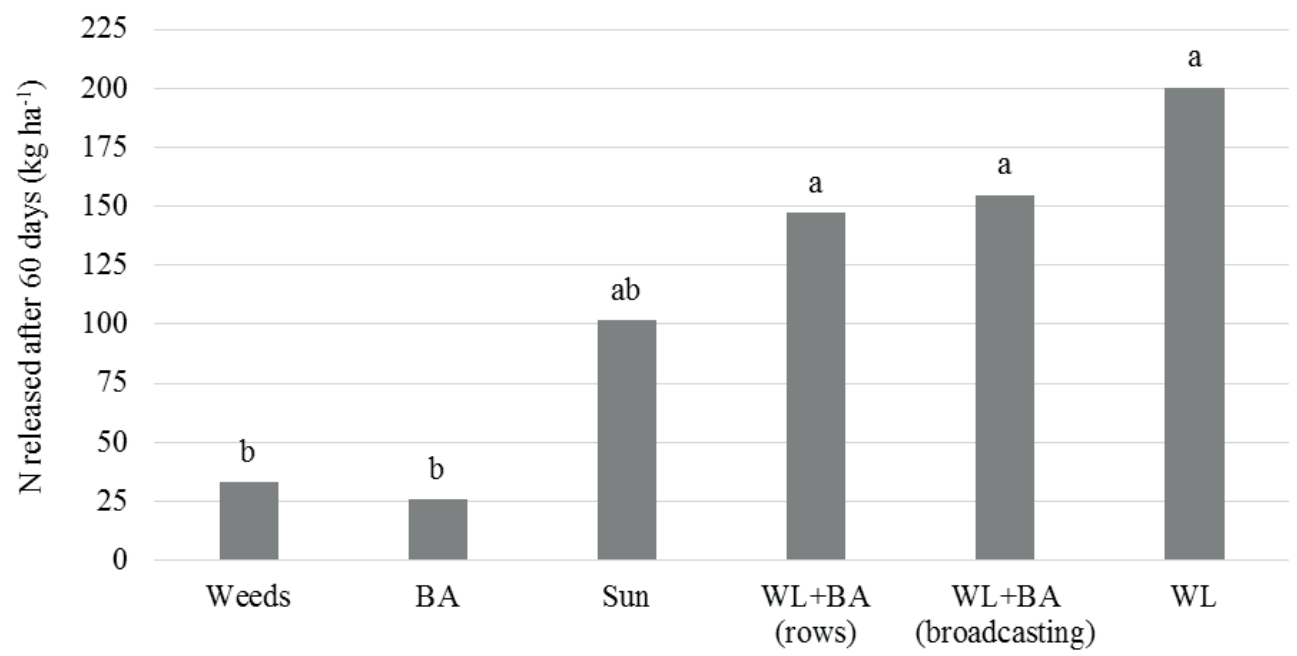

Figure 1. Nitrogen released by the mulch after 60 days of decomposition. BA: black oat; Sun: sunflower; WL + BA (rows): white lupin intercropped with black oat in rows; WL + BA (broadcasting): white lupin intercropped with black oat by broadcasting; WL: white lupin. 
$1.19 \mathrm{~m}, 22.24 \mathrm{~mm}$ and 1, respectively. A number of ears per plant close to 1 indicates good environmental conditions and proper adjustment of plant population (Ceccon et al. 2013).

Jack bean (Canavalia ensiformis) did not affect the agronomic characteristics of maize, and there was no difference between the two cropping methods, except for yield (Table 2). These data partially corroborate the results found by Coelho et al. (2016), where intercropping with a density of 5 jack bean plants $\mathrm{m}^{-1}$ did not influence plant height, first-ear insertion height, stem diameter or prolificacy, but significantly affected the 1,000 grain weight. However, in our study, the 1,000 grain weight was not affected by the intercropping with jack bean.

Of the agronomic characteristics assessed, only 1,000 grain weight and yield were influenced by the treatments, with the former affected only by treatment and the latter by treatment and cropping method (Table 2).

With respect to the 1,000 grain weight, a significant difference was observed only between the treatments using sunflower mulch and white lupin intercropped with black oat (in rows), with no difference for the remaining treatments assessed.

According to Matoso et al. (2015), the nutrient cycling prompted by the decomposition and mineralization of plant residues promotes a better development of the subsequent crop, under a no-tillage system. As a legume applied in the intercropping treatment, white lupin provided nitrogen to the soil during its decomposition. Nitrogen is the nutrient in highest demand by maize crops, and its deficiency may limit grain yield (Farinelli \& Lemos 2012).
Silva et al. (2009) studied the $\mathrm{N}$ accumulation and $\mathrm{C}: \mathrm{N}$ ratio in the intercropping of different species and concluded that cover crops can significantly increase the nitrogen supply in production systems. This explains the fact that the treatment involving white lupin intercropped with black oat (in rows) promoted a better grain weight, when compared to sunflower mulch. The release of nutrients during the decomposition of the cover plant was more efficient when grass and legume species (in rows) were intercropped, if compared to sunflower mulch. This release of nutrients may result in a better grain weight.

The treatments using white lupin mulch in monoculture and intercropped with black oat (planted by broadcasting and in rows) provided the highest yield. This can be attributed to a better weed control, due to the high amount of biomass that these cover crops provide.

Another factor that increased the maize yield in treatments of grass intercropped with legume species and white lupin in monoculture was the release of $\mathrm{N}$ during the mulch decomposition. Lázaro et al. (2013) assessed different cover crops under no-tillage farming and concluded that the maize yield was higher in treatments with mulch from white lupin intercropped with black oat and white lupin alone, with values of $10,508 \mathrm{~kg} \mathrm{ha}^{-1}$ and $9,975 \mathrm{~kg} \mathrm{ha}^{-1}$, respectively. This result may be attributed to a better synchronization of nutrient release by the mulches and absorption by the maize crop (Silva et al. 2007).

Consequently, the rapid decomposition of the legume (low $\mathrm{C}: \mathrm{N}$ ratio) influenced the $\mathrm{N}$ availability in early stages of the maize development, thereby improving yield. Souza \& Pereira (2011) studied plant

Table 2. Average values for 1,000 grain weight and grain yield, as a function of plant cover and cropping with maize alone or intercropped with jack bean (Canavalia ensiformis).

\begin{tabular}{|c|c|c|}
\hline Treatment with cover crop & 1,000 grain weight $(\mathrm{g})$ & Yield $\left(\mathrm{kg} \mathrm{ha}^{-1}\right)$ \\
\hline Weeds & $356 a b^{*}$ & $6,101 \mathrm{c}$ \\
\hline No cover crop & $358 \mathrm{ab}$ & $6,753 \mathrm{bc}$ \\
\hline Black oat & $359 \mathrm{ab}$ & $6,955 \mathrm{bc}$ \\
\hline Sunflower & $332 b$ & $6,034 \mathrm{c}$ \\
\hline White lupin + black oat (rows) & $376 \mathrm{a}$ & $7,812 \mathrm{ab}$ \\
\hline White lupin + black oat (broadcasting) & $372 \mathrm{ab}$ & $7,969 \mathrm{ab}$ \\
\hline White lupin & $367 \mathrm{ab}$ & $8,588 \mathrm{a}$ \\
\hline \multicolumn{3}{|l|}{ Cropping methods } \\
\hline Maize alone & - & $7,493 \mathrm{a}$ \\
\hline Intercropped & - & $6,853 \mathrm{~b}$ \\
\hline
\end{tabular}

* Means followed by the same letter do not differ statistically according to the Tukey test at $5 \%$. 
species used for the formation of mulch in organic no-tillage systems and recorded higher $\mathrm{N}$ levels in winter cover crops of white lupin in monoculture and intercropped with black oat. Nitrogen levels did not decline under intercropping, due to the vigorous growth of white lupin, in relation to black oat.

With regard to maize yield, there was no difference between the intercropped treatments and those without cover crop or black oat in monoculture (Table 2). Lázaro et al. (2013) observed differences in maize yield, when planted after black oat in monoculture and intercropped with white lupin, with average values of 9,180 $\mathrm{kg} \mathrm{ha}^{-1}$ and $10,817 \mathrm{~kg} \mathrm{ha}^{-1}$. These results were higher than those recorded in the present study because the climate in southern Brazil favors these cover crop species. Martins (1994) evaluated the yield potential of a maize variety grown in monoculture without cover crop and found an average yield of $7,133 \mathrm{~kg} \mathrm{ha}^{-1}$.

The weed and sunflower-based cover crops exhibited the lowest yield, with no significant effect observed for black oat in monoculture and no cover crop. Treatments without cover crop resulted in higher weed infestation due to uneven ground cover, which may explain the low yield of maize that competed with the plant species in these treatments.

Coelho et al. (2016) studied the effect of sunflower mulch on maize yield and recorded an average yield of 2,209 $\mathrm{kg} \mathrm{ha}^{-1}$. Carvalho et al. (2004) analyzed maize yield on fallow land (weeds) and found an average of approximately $5,438 \mathrm{~kg} \mathrm{ha}^{-1}$ in the two growing seasons studied.

There was a significant effect between the two cropping methods, whereby maize yield was higher when grown alone than when intercropped with jack bean. According to Fontanétti (2008), the maize production is not affected when intercropped with up to six jack bean plants in the same row, with no competition occurring between the species. Therefore, these results do not corroborate those found in the present study. Intercropping must comply with certain technical criteria, in order to prevent the legume species from competing with maize. As such, it is important to know the soil and climate conditions of the region in question, in order to choose the most appropriate varieties (Fontanétti 2008).

Martins (1994) studied the intercropping of maize with different legume species and concluded that planting legumes simultaneously with maize in the same row reduced crop yield. Corrêa (2009) assessed the maize yield when intercropped with legume species and found results of $3.1 \mathrm{t} \mathrm{ha}^{-1}$ with jack bean at a density of 3 plants $\mathrm{m}^{-1}$ and $6.4 \mathrm{tha}^{-1}$ at six jack bean plants (Canavalia ensiformis), within the same row as maize. Coelho et al. (2016) observed an average yield of $2,000 \mathrm{~kg} \mathrm{ha}^{-1}$ in maize grown alone and 2,686 $\mathrm{kg} \mathrm{ha}^{-1}$ under intercropping. This variation in results depends on the soil and climate conditions in the region and the legume varieties used for intercropping.

\section{CONCLUSIONS}

1. Sunflower, white lupin intercropped with black oat (in rows and by broadcasting) and white lupin are efficient at producing the highest amount of mulch for organic no-tillage farming;

2. Mulch from the white lupin treatment, white lupin intercropped with black oat (in rows and by broadcasting) and sunflower prompts a greater $\mathrm{N}$ release during the decomposition of the crop residues for 60 days;

3. The treatments using mulch from white lupin and black oat intercropped with white lupin increase the maize yield in the organic no-tillage system;

4. Jack bean intercropping in the same row reduces the maize yield potential, when compared to maize cultivated alone, due to competition between the species.

\section{ACKNOWLEDGMENTS}

The authors are grateful to the Coordenação de Aperfeiçoamento de Pessoal de Nível Superior (Capes) and Conselho Nacional de Desenvolvimento Científico e Tecnológico (CNPq), for supporting this study.

\section{REFERENCES}

ALVARENGA, R. C. et al. Plantas de cobertura de solo para sistema plantio direto. Informe Agropecuário, v. 22, n. 208, p. 25-36, 2001.

AMADO, T. J. C.; MIELNICZUK, J.; AITA, C. Recomendação de adubação nitrogenada para o milho no RS e SC adaptada ao uso de culturas de cobertura do solo, sob plantio direto. Revista Brasileira de Ciência do Solo, v. 26, n. 1, p. 241-248, 2002.

AMADO, T. J. C.; MIELNICZUK, J.; FERNANDES, S. B. V. Leguminosas e adubação mineral como fontes 
de nitrogênio para o milho em sistemas de preparo do solo. Revista Brasileira de Ciência do Solo, v. 24, n. 1, p. 179-189, 2000.

BERTÉ, L. N. et al. Características produtivas do milho crioulo e produção de fitomassa no consórcio com diferentes plantas de cobertura. In: CONGRESSO NACIONAL DE MILHO E SORGO, 28., 2010, Goiânia. Anais... Sete Lagoas: Associação Brasileira de Milho e Sorgo, 2010. p. 1253-1258.

CANCELLIER, L. L. et al. Adubação orgânica na linha de semeadura no desenvolvimento e produtividade do milho. Semina: Ciências Agrárias, v. 32, n. 2, p. 527-540, 2011.

CARVALHO, M. A. C. de et al. Produtividade do milho em sucessão a adubos verdes no sistema de plantio direto e convencional. Pesquisa Agropecuária Brasileira, v. 39, n. 1, p. 47-53, 2004.

CECCON, G. et al. Épocas de semeadura de milho safrinha solteiro e consorciado com Brachiaria ruziziensis. In: SEMINÁRIO NACIONAL MILHO SAFRINHA, 12., 2013, Dourados. Anais... Dourados: Embrapa Agropecuária Oeste, 2013. 1 CD-ROM.

COELHO, S. P. Coberturas vegetais no sistema de plantio direto orgânico de milho. 53 f. 2014. Dissertação (Mestrado em Agroecologia) - Universidade Federal de Viçosa, Viçosa, 2014.

COELHO, S. P. et al. Coberturas vegetais na supressão de plantas daninhas em sistema de plantio direto orgânico de milho. Revista Brasileira de Milho e Sorgo, v. 15, n. 1, p. 65-72, 2016.

CORRÊA, M. L. P. Cultivo orgânico de milho em sistema de plantio direto. 115 f. 2009. Tese (Doutorado em Fitotecnia) - Universidade Federal de Viçosa, Viçosa, 2009.

CRUZ, J. C. et al. Produção de milho orgânico na agricultura familiar. Sete Lagoas: Embrapa, 2006. (Circular técnica, 81).

DAROLT, M. R.; SKORA NETO, F. Sistema de plantio direto em agricultura orgânica. Passo Fundo: Aldeia Norte, 2002.

EMPRESA BRASILEIRA DE PESQUISA AGROPECUÁRIA (Embrapa). Centro Nacional de Pesquisa de Solos. Sistema brasileiro de classificação de solos. Rio de Janeiro: Embrapa, 2013.

FAGERIA, N. K.; BALIGAR, V. C.; BAILEY, B. A. Role of cover crops in improving soil and row crop productivity. Communications in Soil Science and Plant Analisys, v. 36, n. 19-20, p. 2733-2757, 2005.

FANCELLI, A. L. Ecofisiologia, fenologia e implicações básicas de manejo. In: BORÉM, A.; GALVÃO, J. C. C.;
PIMENTEL, M. A. Milho: do plantio à colheita. Viçosa: Ed. UFV, 2015. p. 50-76.

FARINELLI, R.; LEMOS, L. B. Nitrogênio em cobertura na cultura do milho em preparo convencional e plantio direto consolidados. Pesquisa Agropecuária Tropical, v. 42, n. 1, p. 63-70, 2012.

FAVARATO, L. F. Plantio direto orgânico de milho-verde sobre diferentes plantas de cobertura. 83 f. 2015. Tese (Doutorado em Fitotecnia) - Universidade Federal de Viçosa, Viçosa, 2015.

FONTANÉTTI, A. Adubação e dinâmica de plantas daninhas em sistema de plantio direto orgânico de milho. 84 f. 2008. Tese (Doutorado em Fitotecnia) - Universidade Federal de Viçosa, Viçosa, 2008.

GONTIJO NETO, M. M. et al. Sistemas de integração lavoura-pecuária-floresta em Minas Gerais. Boletim de Indústria Animal, v. 71, n. 2, p. 183-191, 2014.

HEINRICHIS, R. et al. Cultivo consorciado de aveia e ervilhaca: relação $\mathrm{C} / \mathrm{N}$ da fitomassa e produtividade do milho em sucessão. Revista Brasileira de Ciência do Solo, v. 25, n. 2, p. 331-340, 2001.

LÁZARO, R. D. L. et al. Produtividade de milho cultivado em sucessão à adubação verde. Pesquisa Agropecuária Tropical, v. 43, n. 1, p. 10-17, 2013.

MARTINS, D. Comunidade infestante no consórcio de milho com leguminosas. Planta Daninha, v. 12, n. 2, p. 100-105, 1994.

MATOSO, A. O. de et al. Desempenho agronômico da cultura do milho sob diferentes plantas de cobertura no Cerrado. Tecnologia \& Ciência Agropecuária, v. 9, n. 3, p. 29-34, 2015.

MELLO, E. S.; BRUM, A. L. O direito ao desenvolvimento e a produção local: o plantio direto da soja como uma alternativa de desenvolvimento econômico. Revista Gestão e Desenvolvimento em Contexto, v. 1, n. 1, p. 133-154, 2013.

MÔRO, G. V.; FRISCHE-NETO, R. Importância e uso do milho no Brasil. In: BORÉM, A.; GALVÃO, J. C. C.; PIMENTEL, M. A. Milho: do plantio à colheita. Viçosa: Ed. UFV, 2015. p. 9-25.

RAMOS, A. M.; SANTOS, L. A. R.; FORTES, L. T. G. (Eds.). Normais climatológicas do Brasil, 1961-1990. Brasília, DF: INMET, 2009.

REZENDE, C. P. et al. Litter deposition and disappearance in brachiaria pastures in the Atlantic Forest region of south of Bahia, Brazil. Nutrient Cycling in Agroecosystems, v. 54, n. 1, p. $99-112,1999$.

SILVA, F. C. Manual de análises químicas de solos, plantas e fertilizantes. Rio de Janeiro: Embrapa Solos, 2009. 
SILVA, A. A. et al. Sistemas de coberturas de solo no inverno e seus efeitos sobre o rendimento de grãos do milho em sucessão. Ciência Rural, v. 37, n. 4, p. 928935, 2007.

SILVA, F. de A. S.; AZEVEDO, C. A. V. The Assistat software version 7.7 and its use in the analysis of experimental data. African Journal of Agricultural Research, v. 11, n. 39, p. 3733-3740, 2016.

SILVA, P. C. G. da et al. Fitomassa e relação $\mathrm{C} / \mathrm{N}$ em consórcios de sorgo e milho com espécies de cobertura.
Pesquisa Agropecuária Brasileira, v. 44, n. 11, p. 15041512, 2009.

SOUZA, J. L. de; PEREIRA, V. A. Espécies para formação de palhada para plantio direto em sistema orgânico, no verão e inverno em regiões de altitude. Horticultura Brasileira, v. 29, n. 2, p. S4223-S4230, 2011.

WUTKE, E. B.; CALEGARI, A.; WILDNER, L. P. Espécies de adubos verdes e plantas de cobertura e recomendações para o seu uso. In: LIMA FILHO, O. F. et al. (Eds.). Adubação verde e plantas de cobertura no Brasil: fundamento e práticas. Brasília, DF: Embrapa, 2014. 